\begin{tabular}{|l|l|l|l|l|l|}
\hline J. Tek. Ling & Vol. 13 & No. 2 & Hal. $131-140$ & Jakarta, Mei 2012 & ISSN 1441-318X \\
\hline
\end{tabular}

\title{
UJI COBA KINERJA BAKTERI KARBONOKLASTIK PADA TANAH TERCEMAR MINYAK BUMI DENGAN TEKNIK LANDFARMING
}

\author{
Nida Sopiah ${ }^{1}$, Arifudin $^{2}$ \\ Peneliti1) dan Perekayasa ${ }^{2)}$ di Balai Teknologi Lingkungan \\ Badan Pengkajian Penerapan Teknologi \\ nidasofiah@yahoo.com
}

\begin{abstract}
Tantangan dalam proses bioremediasi selain senyawa yang didegradasi merupakan senyawa kompleks juga mengandung senyawa rekalsitran yang sulit didegradasi dan bersifat toksik, sehingga menyebabkan laju degradasinya berjalan lambat. Seleksi, bakteri dan optimasi bakteri pada bioremediasi lahan tercemar minyak bumi sangat diperlukan agar bakteri yang bekerja pada proses bioremediasi mampu beradaptasi dan mendegradasi.Tujuan dari Penelitian ini adalah mengoptimasi kinerja bakteri karbonoklastik dengan menetapkan media tumbuh bakteri yang mampu menginduksi terbentuknya biosurfaktan; menentukan komposisi campuran (minyak bumi, tanah dan bulking agent) yang optimal serta uji kinerja bakteri karbonoklastik dengan menggunakan teknik landfarming. Dari hasil uji coba tersebut diperoleh media tumbuh yang digunakan dalam perbanyakan ketiga bakteri karbonoklastik R122-2.3, R122-5 dan R122-BN5 adalah media MM2; sedangkan komposisi campuran yang digunakan dalam teknik landfarming mempunyai rasio $6: 80: 14$ (minyak : tanah : Kompos) dengan nilai porositas dan water holding capacity sebesar $45 \%$ dan nilai bulk density $1.04 \mathrm{gram} / \mathrm{mL}$. Uji kinerja bakteri karbonoklastik R122-BN5 dengan teknik landfarming mampu menurunkan nilai TPH dari $6,8 \%$ menjadi lebih kecil dari $1 \%(0,82 \%)$ selama 32 hari.
\end{abstract}

Kata kunci : bioremediasi, minyak bumi, rekalsitran, bakteri hidrokarbonoklastik, biosurfaktan

\begin{abstract}
A challenge on applying bioremediation to soils contaminated with crude oil is the recalcitrant and toxic properties of the oil as such preventing it from readily biodegradation. To overcome the problem a selection process and optimization of microbial consortia must be undertaken so that the bacteria could adapt and perform optimally in the bioremediation. The purpose of this study were optimizing hydrocarbonoclastic bacteria by formulating medium for microbial growth so that able to produce biosurfactant, determining optimal composition of microbial matrix (crude oil, soil, and bulking agent), and testing the consortia and matrix on a landfarming trial. Results of the experiment demonstrated a medium MM2 capable of facilitating the growth of R122-2.3, R122-5 and R122-BN5 consortia. Furthermore, the optimal composition of matrix for bioremediation was $6: 80: 14$ (crude oil : soil : compost) that having properties porosity $45 \%$, water holding capacity $45 \%$ and bulk density $1.04 \mathrm{~g} \mathrm{~cm}-3$. Performance test of hydrocarbonoclastic bacteria of R122-BN5 With this landfarming technique a level of TPH from $6,8 \%$ could be reduced to less than $1 \%$ for 32 days.
\end{abstract}

Keywords: bioremediation, crude oil, recalcitrant, bacteria, biosurfactant 


\section{PENDAHULUAN}

\subsection{Latar Belakang}

Kegiatan eksplorasi dan eksploitasi terhadap sumber daya alam selain memberikan sumbangsih yang besar bagi pertumbuhan ekonomi Indonesia juga berpotensi menyebabkan peningkatan resiko pencemaran dan perusakan lingkungan. Kontaminasi tanah oleh minyak bumi merupakan hal yang seringkali terjadi pada aktivitas industri sektor Minyak dan Gas, berpotensi menimbulkan dampak terhadap lingkungan baik secara biologi, geologi, fisik, kimia dan sosekbud.Salah satu upaya yang dilakukan untuk mengatasi pencemaran minyak bumi di tanah dapat dilakukan dengan teknik bioremediasi.Bioremediasi merupakan suatu teknologi yang ramah lingkungan, yang mana bakteri memegang peranan yang sangat penting dalam proses degradasi limbah biologi. ${ }^{1)}$

Proses degradasi limbah ini dilakukan dengan memanfaatkan bakteri yang memanfaatkan limbah ini sebagai sumber karbon atau sumber nutrisi. Untuk meningkatkan keefektifan penggunaan mikroorganisma dalam bioremediasi dapat dilakukan dengan melakukan dua strategi, yaitu biostimulation yaitu suatu teknik menambahkan nutrisi tertentu dengan tujuan merangsang aktivitas mikroorganismamikroorganismasetempat (indigenous); dan yang kedua adalah bioaugmentasi, yaitu dengan mengintroduksi mikroorganisma tertentu pada daerah yang akan diremediasi. Dalam beberapa hal, teknik bioaugmentasi juga diikuti dengan penambahan nutrisi tertentu. ${ }^{(2,3)}$

Proses bioremediasi akan berjalan cepat apabila limbah organik merupakan senyawa yang mampu didegradasi oleh mikroorganisma dan produk degradasinya merupakan senyawa sederhana yang aman bahkan diperlukan bagi lingkungan. Akan tetapi bila limbah yang didegradasinya merupakan senyawa rekalsitran, maka laju degradasi akan berjalan lambat ${ }^{(4)}$ Lambatnya laju degradasi limbah organik di lingkungan dapat disebabkan oleh beberapa faktor, antara lain : enzim-enzim degradatif yang dihasilkan oleh mikroorganisma tidak mampu mengkatalis reaksi degradasi limbah yang tidak alami, kelarutan polutan dalam air sangat rendah, dan limbah organik bersifat toksik bagi mikroorganisma tersebut. Selain itu, pengaruh lingkungan seperti $\mathrm{pH}$, temperatur, dan kelembaban tanah juga sangat berperan dalam menentukan kesuksesan proses bioremediasi ${ }^{(3,4)}$.

Seleksi dan optimasi bakteri pada bioremediasi lahan tercemar minyak bumi sangat diperlukan agar bakteri yang bekerja pada proses bioremediasi mampu beradaptasi dan mendegradasi secara optimal. Oleh karena itu bakteri yang terlibat dalam proses bioremediasi bukanlah bakteri tunggal melainkan konsorsium bakteri yang mampu memanfaatkan hidrokarbon sebagai substrat, bakteri yang mampu mendegradasi hidrokarbon juga bakteri yang mampu menghasilkan biosurfaktan. Dengan dihasilkannya biosurfaktan tersebut dapat menurunkan tegangan antar muka, sehingga bakteri pendegradasi dapat bekerja secara optimal. ${ }^{(3,4,5)}$.

Pada penelitian ini digunakan teknik landfarming, yaitu salah satu teknik bioremediasi yang dikenal relatif lebih murah dan mudah dikerjakan. Untuk mempercepat proses bioremediasinya selain digunakan bakteri karbonoklastik yang telah diseleksi terlebih dahulu juga dilakukan penambahan nutrisi yang dibutuhkan bakteri dalam proses bioremediasi.

\subsection{Tujuan}

Tujuan dari Penelitian ini adalah

a) mengoptimasi bakteri karbonoklastik dengan menentukan media tumbuh yang optimum bagi pertumbuhan bakteri.

b) menentukankomposisi campuran (minyak bumi, tanah dan bulking agent) 
yang optimal untuk digunakan dalam uji kerja bakteri karbonoklastik.

c) Melaksanakan uji kinerja bakteri karbonoklastik dengan menggunakan teknik landfarming.

\section{METODE PENELITIAN}

\subsection{Optimasi Media Tumbuh Bakteri Karbonoklastik}

a) Peremajaan Isolat Bakteri

Peremajaan isolat dilakukan untuk menghindari terjadinya mutasi pada isolat dengan demikian peremajaan ini perlu dilakukan untuk mempertahankan biakan isolat murni.

b) Penetapan Jumlah Populasi Bakteri

Penetapan jumlah populasi bakteri dilakukan untuk mengetahui grafik pertumbuhan bakteri, sehingga diperoleh kecepatan biak (generation time) dari koloni bakteri tersebut.

c) Optimasi Media Tumbuh Bakteri

Untuk menetapkan media tumbuh yang akan digunakan dalamperbanyakan bakteri, dilakukan uji tumbuh bakteri pada dua media molase dengan komposisi yang berbeda (MM1 dan MM2). Uji ini dilakukan untuk mendapatkan media tumbuh bakteri yang akan digunakan dalam proses perbanyakan bakteri.Kecepatan tumbuh bakteri diamati dengan mengukur grafik pertumbuhan bakteri pada kedua media dengan mengukur tingkat kekeruhan menggunakan spektrofotometer.

\subsection{Uji Coba Bioremediasi Dengan Teknik Landfarming}

a) Preparasi Media Tanah

Preparasi Media Tanah dilakukan untuk mendapatkan tanah yang digunakan sebagai media pencampur dalam membuat komposisi campuran. Dalam tahap preparasi media tanah ini terlebih dahulu tanah dibersihkan dari alang-alang dan semak belukar. Tanah digali dengan menggunakan cangkul selanjutnya dilakukan proses penyaringan untuk mendapatkan ukuran yang sama yaitu sekitar $1-2 \mathrm{~cm}$.

b) Uji Pendahuluan

Percobaan pembuatan komposisi campuran yang terdiri dari minyak, tanah dan bulking agent dilakukan dengan mencampurkan tanah yang telah dipreparasi, dengan bulking agent dan minyak. Untuk mendapatkan campuran yang homogen, campuran dimasukan kedalam wadah dan diaduk. Pada percobaan ini bulking agent yang digunakan berupa kompos yang diproduksi di Kawasan Puspiptek Serpong. Kompos ini dibuat dari dedaunan dan ranting yang banyak terdapat di areal Kawasan Puspiptek.

Kriteria komposisi yang optimal yang utama adalah porositas dan water holding capacity. Porositas akan menentukan keberhasilan suplai udara (untuk teknik landfarming berupa aerasi pasif) dan water holding capacity akan mempengaruhi kadar air yang dapat ditahan oleh campuran secara baik. Pada uji pendahuluan ini dibuat beberapa komposisi campuran, dan masing-masing campuran tersebut diukur nilai porositas dan water holding capacity.

Aspek yang perlu diperhatikan dalam pembuatan campuran adalah homogenitas campuran. Selain itu juga dilakukan pengukuran nilai bulk density dan kadar air.Setelah mendapatkan campuransebagaimana tersebut di atas, selanjutnya diukur porositas.

2.3 Aplikasi Bakteri Karbonoklastik Hasil Seleksi pada Bioremediasi Lahan Tercemar Minyak Bumi dengan Teknik Landfarming Skala Laboratorium.
a) Start up Percobaan Landfarming
Campuran yang telah homogen dimasukan kedalamSembilan buah reaktor 
landfarming.

Start up percobaan landfaming dimulai dengan melakukan pengujian terhadap ketiga bakteri pendegradasi hidrokarbon (R122-2.3; R122-5; R-122-BN5) ke dalam masingmasing reaktor dengan masing-masing ulangan sebanyak tiga kali. Selanjutnya kesembilan reaktor tersebut ditambahkan nutrisi. Penambahan bakteri dilakukan dengan menggunakan penyiram tanaman atau gembor lalu dilakukan pengadukan agar menghasilkan sebaran bakteri dan nutrisi yang merata di seluruh permukaan landfarming.

b) Monitoring Proses Landfarming

Monitoring proses landfarming dilakukan untuk mengevaluasi kinerja masing-masing bakteri dengan membandingkan besarnya penurunan nilai TPH (Total Petroleum Hidrokarbon), meningkatnya konsentrasi karbondioksida, penurunan Oksigen, suhu, $\mathrm{pH}$ dan pemantauan terhadap kadar air. Dalam percobaan ini monitoring terhadap suhu, pH dilakukan menggunakan soil tester, kadar air menggunakan alat moisturemeter, konsentrasi $\mathrm{O}_{2}$ dan $\mathrm{CO}_{2}$ diukur menggunakan alat gas analyzer dari tumpukan tanah, dengan frekwensi pengukuran diakukan setiap hari, sedangkan pengukuran Total Petroleum Hydrokarbon (TPH), dilakukan dengan frekwensi pengukuran satu kali dalam seminggu menggunakan alat sokhletasi dengan pelarut ekstraksi menggunakan heksan-aseton (1:1).

\section{HASIL DAN PEMBAHASAN}

\subsection{Optimasi Media Tumbuh Bakteri}

Aktivitas bakteri dalam mendegradasi senyawa hidrokarbon merupakan kunci utama dalam proses biodegradasi. Faktor yang sangat berperan dalam biodegradasi senyawa hidrokarbon tersebut selain dari jenis bakteri yang digunakan merupakan konsorsium bakteri yang mampu mendegradasi, mentransformasi dan mengimobilisasi bahan pencemar sehingga dapat terurai secara alami ${ }^{(6)}$ juga diperlukan komposisi media tumbuh yang tepat sehingga proses biodegradasinya berjalan secara optimal.

Dari hasil uji optimasi media tumbuh ditetapkan media pertumbuhan yang paling baik adalah media pertumbuhan MM2 dengan rasio C:N:P sebesar 100:5:1.Grafikgrafik yang menunjukkan pertumbuhan mikroba ditunjukkan pada Gambar 3.1; 3.2 dan 3.3.

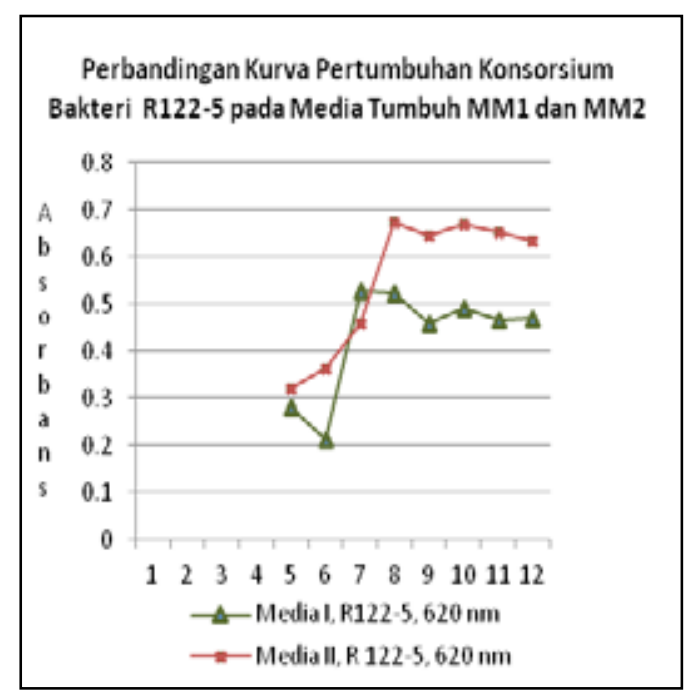

Gambar 3.1 Kurva pertumbuhan bakteri 122-5 pada Media MM1 dan MM2

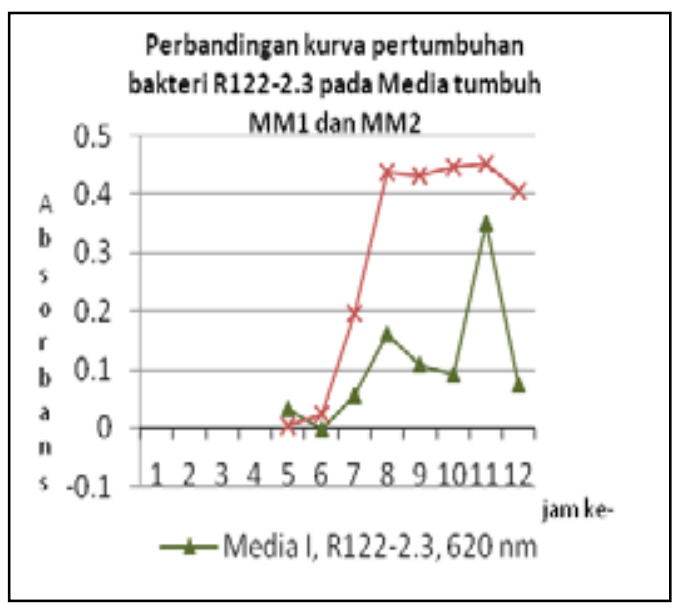

Gambar 3.2. Kurva pertumbuhan bakteri RISTEK 122-2.3 pada Media MM1 dan MM2 


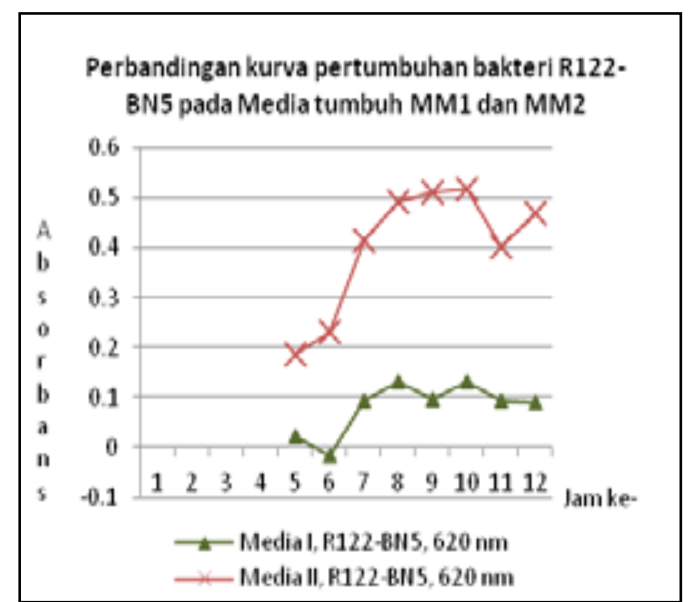

Gambar 3.3. Kurva pertumbuhan bakteri RISTEK 122-BN5 pada Media MM1 dan MM2

Selain faktor populasi bakteri, nutrisi, faktor lain yang yang juga berperan dalam proses biodegradasi hidrokarbon adalah komposisi matriks tanah ${ }^{(6)}$. Komposisi tanah dengan jumlah bahan organik yang besar akan mampu membuat ruang berpori. Ruang berpori dibentuk oleh adanya perbedaan agregat penyusun pada matrik tanah, kemudian ruang berpori ini di isi oleh air dan udara sehingga kadar air akan besar. Dari gambar3.4 terlihat, bahwa kandungan kompos sangat berpengaruh dalam besaran kadar air campuran. Sampel A dengan perbandingan berat minyak : tanah : kompos (6 : 94 : 0) memiliki kadar air $9.53 \%$ dan sampel $E$ dengan perbandingan berat minyak : tanah : kompos $(6: 75: 19)$ memiliki kadar air sebesar $11.68 \%$.

Dari hasil pengujian kadar air pada berbagai komposisi tanah, minyak dan bulking agent (kompos) menunjukan, bahwa kadar air pada sampel dengan kode $F$ (minyak: tanah : Kompos $=6: 66: 28$ ) memiliki nilai kadar air yang paling besar dibandingkan dengan sampel lainnya, besarnya kadar air ini disebabkan karena kandungan kompos yang terdapat pada sampel $\mathrm{F}$ lebih tinggi dibandingkan dengan kandungan kompos dalam sampel lainnya. Besarnya bahan organik yang terkandung dalam komposisi tersebut mengakibatkan meningkatnya kemampuan dalam menyerap air.

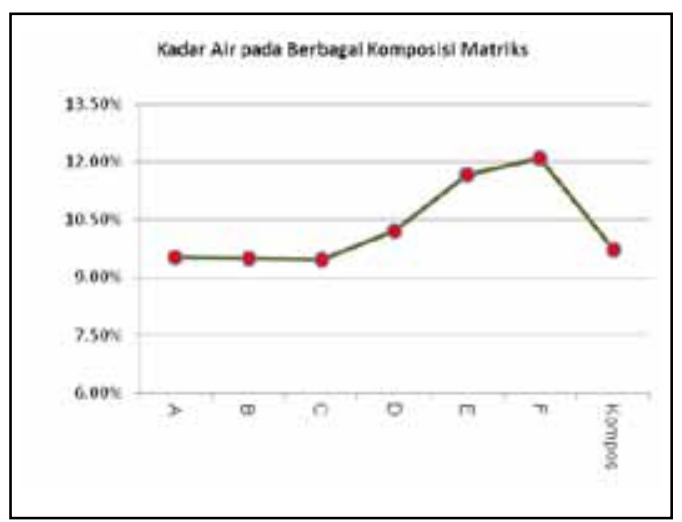

Gambar3.4 Hasil pengukuran kadar air pada berbagai komposisi

Penambahan kompos dalam campuran menyebabkan campuran menjadi lebih gembur dan menambah porositas seperti terlihat dalam gambar 3.5. Sampel A dengan tanpa penambahan kompos memiliki porositas $38 \%$ dan D dengan penambahan kompos sebesar $14 \%$ memiliki porositas

Tabel 3.1 Hasil pengujian kadar air, density, porositas dan water holding capacity (WHC)

\begin{tabular}{|c|c|c|c|c|c|c|c|c|}
\hline No & Kode sampel & Oil (\%) & Tanah (\%) & Kompos (\%) & Kadar Air (\%) & BD (gr/ml) & Porositas (\%) & WHC (\%) \\
\hline 1 & A & 6 & 94 & 0 & 9.53 & 1.15 & 38 & 41 \\
\hline 2 & B & 6 & 90 & 5 & 9.48 & 1.15 & 40 & 40 \\
\hline 3 & C & 6 & 85 & 9 & 9.45 & 1.04 & 44 & 38 \\
\hline 4 & D & 6 & 80 & 14 & 10.21 & 1.04 & 45 & 45 \\
\hline 5 & E & 6 & 75 & 19 & 11.68 & 1.02 & 47 & 43 \\
\hline 6 & F & 6 & 66 & 28 & 12.09 & 0.91 & 50 & 45 \\
\hline 7 & Kompos & - & - & - & 9.73 & 0.36 & - & - \\
\hline
\end{tabular}


sebanyak $45 \%$. Dalam percobaan ini nilai porositas terbesar di jumpai pada sampel $\mathrm{F}$ dengan perbandingan berat minyak : tanah : kompos $=6: 66: 28$ sebesar $50 \%$. sehingga rongga makro akan terisi oleh udara dan rongga mikro akan terisi oleh air (Gambar 3.6).

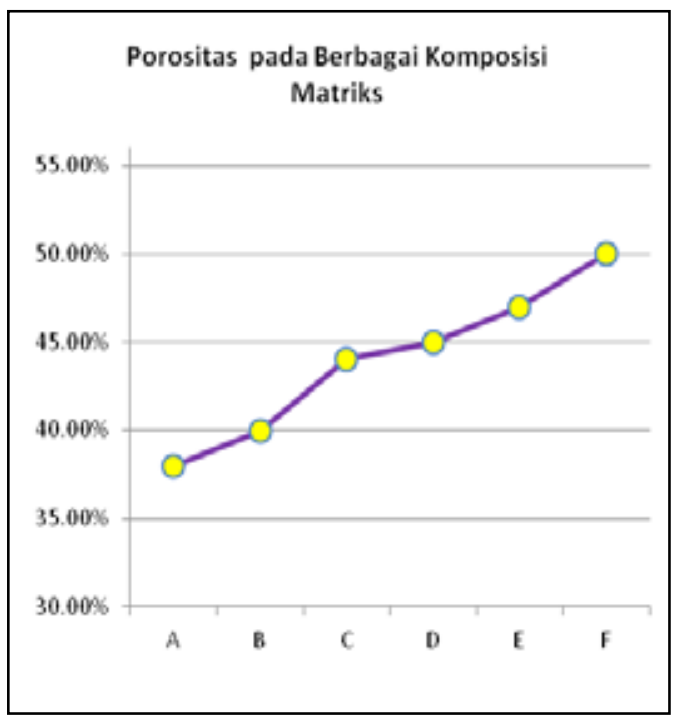

Gambar 3.5 Hasil pengukuran porositas pada berbagai komposisi.

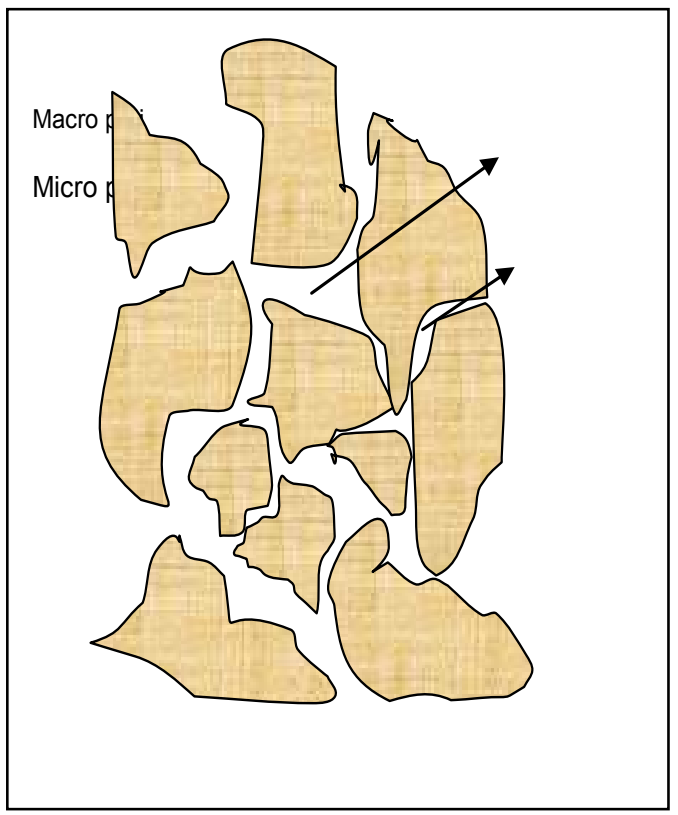

Gambar 3.6. Ruang berpori dalam tanah
Porositas yang tinggi akan menyebabkan udara akan dengan mudah masuk kedalam matrik tanah dengancara melewatirongga antar agregat. Banyaknya rongga-rongga antar agregat mengakibatkan air akan dengan mudah masuk kedalam komposisi campuran, Komposisi campuran atau matrik tanah dikatakan optimal jika suatu campuran memiliki nilai porositas yang besar dan kemampuan dalam menyerap dan menahan air lebih besar (WHC), serta memiliki kandungan bahan pencemar yang besar dalam campuran. Spesifik porositas merupakan parameteryang menyatakan hubungan antara nilai porositas dan kandungan minyak dalam campuran, sedangkan spesifik WHC adalah parameter yang menyataka dalam campuran hubungan antara nilai WHC dan kandungan minyak

Gambar 3.7 menunjukan bahwa sampel D memiliki nilai spesifik porositas dan spesifik water holding capacity yang besar serta mengandung nilai bulk density 1.04 gram/ml, sehingga sampel D merupakan sampel komposisi campuran yang optimal yang selanjutnya akan digunakan dalam proses landfarming skala laboratorium kapasitas 40 kg.

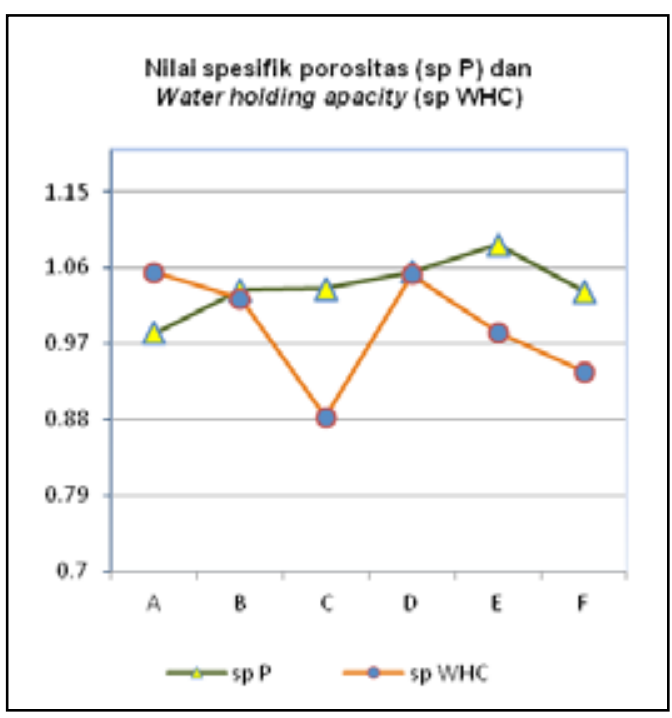

Gambar 3.7Nilai spesifik porositas dan water holding capacity $(\mathrm{WHC})$ 


\subsection{Aplikasi bakteri karbonoklastik pada bioremediasi lahan tercemar minyak bumi dengan teknik landfarming skala lab kapasitas $\mathbf{4 0}$ kg.}

Salah satu faktor yang mempengaruhi pertumbuhan dan aktivitas bakteri adalah penyediaaan nutrisi yang sesuai untuk kultivasi bakteri. Meskipun nutrisi yang digunakan amat beragam, namun sebagai makhluk hidup bakteri mempunyai kebutuhan dasar yang sama, yaitu meliputi air, karbon, dan mineral ${ }^{(6,7)}$.

Adanya aktivitas bakteri dalam mendegradasi senyawa hidrokarbon akan menyebabkan terjadinya peningkatan suhu lingkungan. Suhu yang semakin tinggi dapat meningkatkan metabolisme hidrokarbon menjadi maksimum, yaitu $30^{\circ} \mathrm{C}-45^{\circ} \mathrm{C}$. Di atas suhu ini, aktivitas enzim akan menurun dan toksisitas hidrokarbon pada membran sel akan semakin tinggi ${ }^{(8)}$. Pada Gambar 3.8 terlihat bahwa suhu pada masing-masing reaktor landfarming pada hari pertama menunjukan nilai yang cukup tinggi yaitu berkisar antara $35^{\circ} \mathrm{C}$ hingga $45^{\circ} \mathrm{C}$, suhu tertinggi terjadi pada reaktor dengan penambahanR122-2.3 sedangkan suhu terendah terjadi pada reaktor dengan penambahan R122-5. Rendahnya suhu pada reaktor dengan penambahan R122-5 disebabkan pada hari ke-0 pada reaktor tersebut pemberian nutrisitidak ditambahkan. Setelah dilakukan penambahan pada hari kedua, suhu padareaktor R122-5 mengalami peningkatan suhu hingga mencapai $45^{\circ} \mathrm{C}$.

Pada hari keempat nilai suhu pada masing-masing reaktor mengalami penurunan, hal ini disebabkan konsentrasi kadar minyak berupa total petroleum hidrokarbon sebagai sumber energi mengalami penurunan yaitu dari nilai TPH awal $6,8 \%$ menjadi $3 \%$

Untuk meningkatkan aktivitas bakteri, kedalam landfarming ditambahkan nutrisi sebanyak $1 / 6$ dari penambahan nutrisi awal. Hasil pengukuran suhu menunjukan bahwa adanya kenaikan suhu setelah penambahan nutrisi yaitu pada awal minggu kedua nilai suhu sekitar $28^{\circ} \mathrm{C}$ dan setelah dilakukan penambahan nutrisi dan pengadukan nilai suhu naik menjadi $33^{\circ} \mathrm{C}$, pada minggu kelima, bakteri karbonoklastik mampu menurunkan TPH hingga < 1\% (Gambar.3.9).

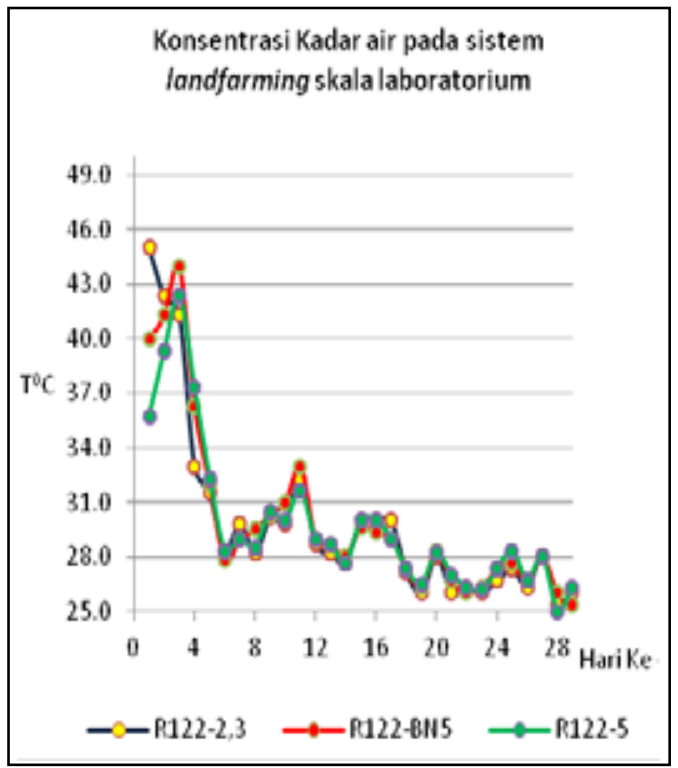

Gambar 3.8 Perubahan suhu berbagai perlakuan bakteri karbonoklastikreaktor Landfarming

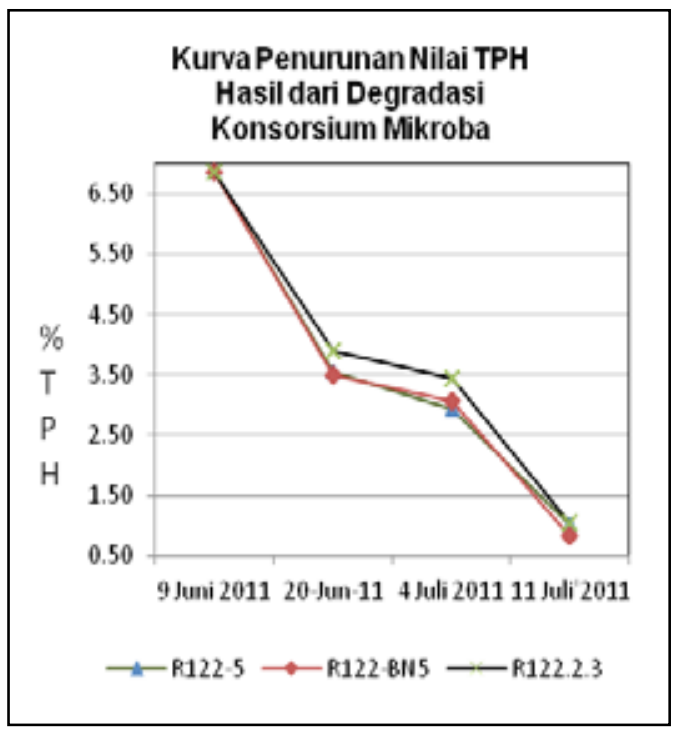

Gambar 3.9 Kurva Penurunan nilai TPH hasil degradasi bakteri karbonoklastik 

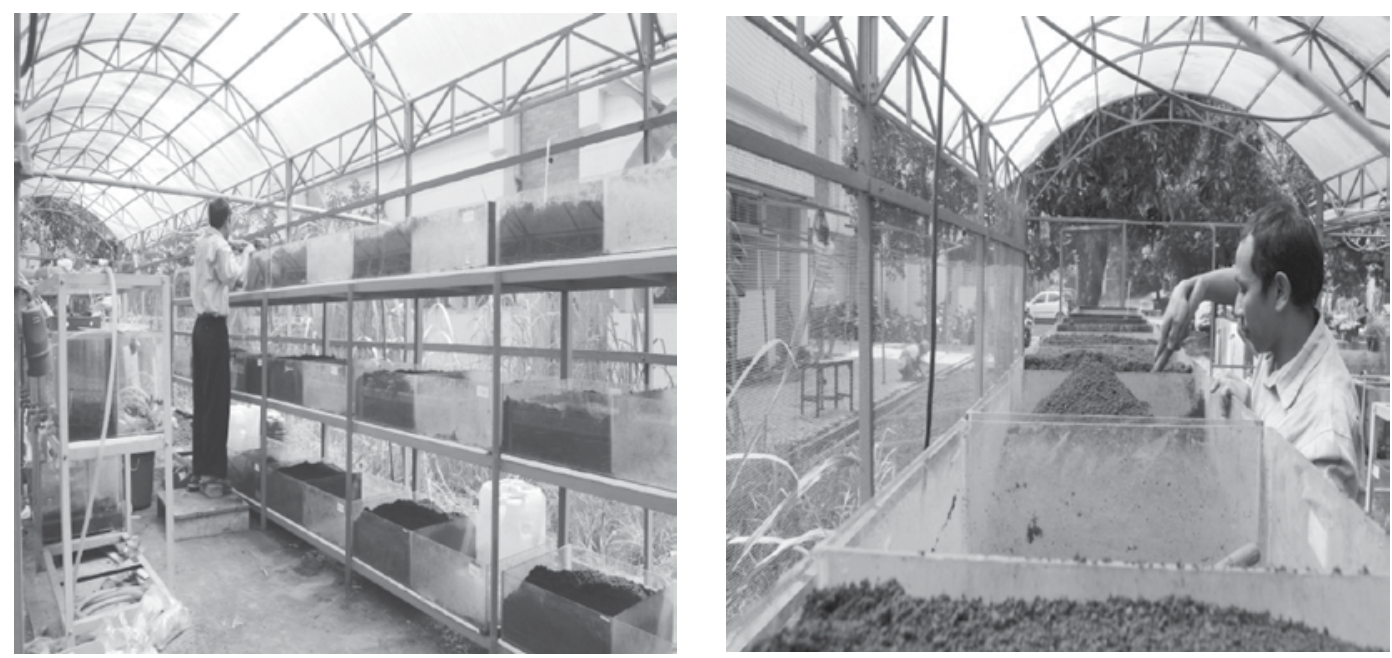

Gambar 5.18 Aplikasi bakteri hasil seleksi pada bioremediasi lahan tercemar minyak bumi dengan teknik landfarming skala lab kapasitas $40 \mathrm{~kg}$

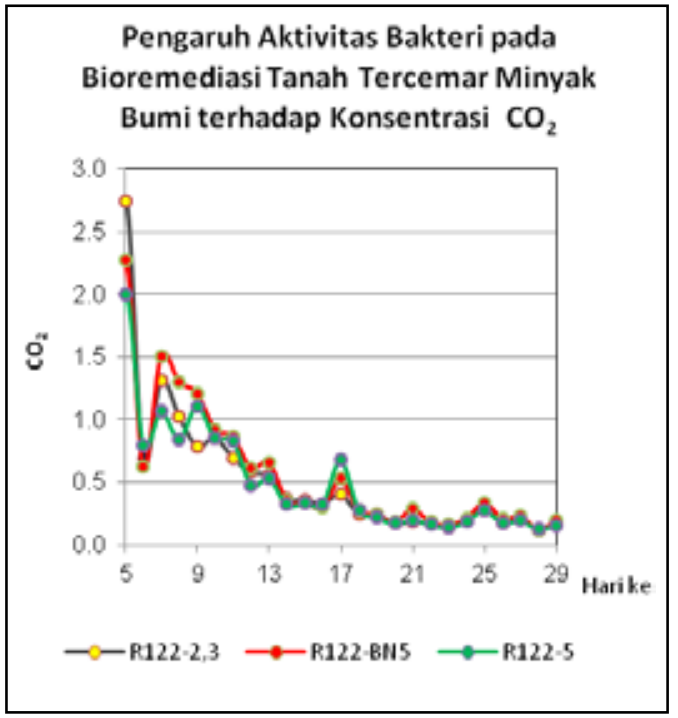

Gambar 3.11 Pengukuran $\mathrm{CO}_{2}$ pada reaktor landfarming

Pengaruh aktivitas bakteri pada proses bioremediasi minyak bumi akan menyebabkan naiknya karbondioksida. Hal ini disebabkan karena adanya respirasi bakteri dan terdegradasinya senyawa hidrokarbon menjadi senyawa karbondioksida. Gambar 3.11 menunjukan bahwa pengukuran konsentrasi $\mathrm{CO}_{2}$ pada minggu pertama berkisar antara $0.6 \%$ hingga $2.7 \%$. Sedangkan reaktor dengan

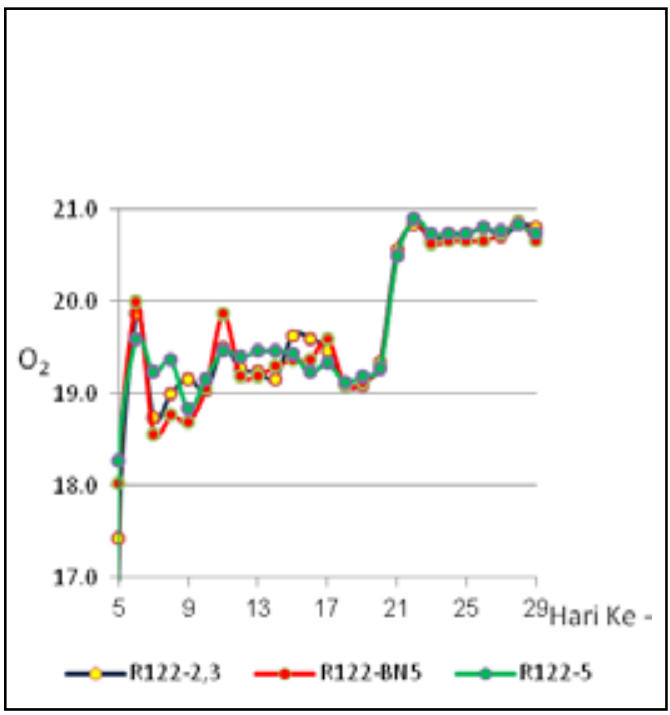

Gambar 3.12 Pengukuran $\mathrm{O}_{2}$ pada reaktor

penambahan bakteri karbonoklastik R1222.3 memiliki nilai konsentrasi yang tertinggi yaitu $2.7 \%$. Tingginya konsentrasi $\mathrm{CO}_{2}$ menunjukan tingginya aktivitas bakteri pendegradasi. Semakin tinggi konsentrasi $\mathrm{CO}_{2}$, berarti semakin tinggi tingkat respirasi bakteri, yang juga menunjukkan tingginya aktivitas bakteri.

Pengukuran konsentrasi $\mathrm{CO}_{2}$ pada minggu-minggu berikutnya, nilai $\mathrm{CO}_{2}$ 
mengalami kecendrungan mengalami penurunan. Hal ini menunjukan menurunnya aktivitas bakteri.

Pengukuran Oksigen (Gambar3.12) pada masing-masing reaktor landfarming,menunjukkanbahwa pada minggu pertama proses pengukuran nilai konsentrasi $\mathrm{O}_{2}$ masih cukup rendah yaitu berkisar antara $17.4 \%$ hingga $20.6 \%$. Pada minggu-minggu berikutnya nilai konsentrasi $\mathrm{O}_{2}$ mengalami kenaikan hingga $19.6 \%$. Pada pengukuran minggu pertama nilai terendah terjadi pada sampel R122-2.3 yaitu $17.4 \%$, rendahnya nilai kosentrasi $\mathrm{O}_{2}$ menunjukan adanya aktivitas bakteri pendegradasi. Penurunan konsentrasi $\mathrm{O}_{2}$ ini sejalan dengan meningkatnya suhu dan konsentrasi $\mathrm{CO}_{2}$. Dan sebaliknya, ketika konsentrasi $\mathrm{O}_{2}$ cenderung meningkat, maka suhu dan konsentrasi $\mathrm{CO}_{2}$ cenderung menurun.

\section{KESIMPULAN DAN SARAN}

\subsection{Kesimpulan}

Dari hasil optimasi kinerja bakteri karbonoklastik R122-2.3, R122-5 dan R122-BN5 diperoleh media tumbuh yang digunakan dalam perbanyakan ketiga bakteri karbonoklastik tersebut adalah media MM2; sedangkan komposisi campuran yang digunakan dalam teknik landfarming mempunyai rasio $6: 80: 14$ (minyak : tanah : Kompos)dengan nilai porositas dan water holding capacity sebesar $45 \%$ dan nilai bulk density $1.04 \mathrm{gram} / \mathrm{mL}$. Uji kinerja bakteri karbonoklastik R122-BN5 dengan teknik landfarming mampu menurunkan nilai TPH fraksi heksan-aseton dari $6,8 \%$ menjadi lebih kecil dari $1 \%(0,82 \%)$ selama 32 hari.

\subsection{Saran}

Kinerja bakteri karbonoklastik sangat bergantung kepada ketersediaan nutrisi , sehingga pemantauan terhadap ketersediaan nutrisi mutlak diperlukan. selama proses bioremediasi berlangsung.

\section{UCAPAN TERIMA KASIH}

Kegiatan ini dapat terlaksana dengan adanya Program Insentif Riset Peningkatan Kemampuan Peneliti dan Perekayasa (PKPP) Tahun 2011 serta peran aktif rekan-rekan satu tim dan rekan-rekan Balai Teknologi Lingkungan BPPT. Terima kasih atas dukungannya.

\section{DAFTAR PUSTAKA}

1. Afriyanti D. 2007, Pemanfaatan Calopogonium mucunoides, bakteri petrofilik dan cendawan mikoriza arbuskula untuk bioremediasi tanah gambut yang terkontaminasi petroleum hidrokarbon secara ex situ. Institut Pertanian Bogor. Bogor

2. Kardena, E. 2003. "Persistent Oeganic Pollutans" (POPs) dan Peran Organisme dalam Proses Detoksifikasi di Lingkungan, Buku Abstrak Peran Mikrobiologi dalam Pemanfaatan Biodiversitas Tropis bagi Pengembangan Industri, Pertanian, Lingkungan dan Pengendalian penyakit. Pertemuan IImiah Tahun 2003, Perhimpunan Mikrobiologi Indonesia, 28-29.

3. Sopiah, N., Mulyono dan S Sulistia. 2011. Kajian Potensi Biosurfaktan Isolat Bakteri Terseleksi untuk Dimanfaatkan dalam Bioremediasi Tanah Tercemar Minyak Bumi, Jurnal Kualitas Lingkungan Hidup "ECOLAB". Vol 5(1). hal 28-34. Pusarpedal-KNLH

4. Sopiah, N., A.N. Oktaviani., S. Sulistia., F. Suciati., D.B. Aviantara. 2011, Isolasi dan Identifikasi Bakteri Pendegradasi Hidrokarbon yang Berasal dari Tanah Tercemar Minyak Bumi, JTL, Vol 12 (3). Hal 291-298, BPPT

5. Kadarwati, S., Sri dan Sugihardjo, 2001, Lembaran Publikasi LEMIGAS, 38(2) 
6. Wahidin N.N. 2010. Bioremediasi Limbah Minyak Berat secara Pengomposan Menggunakan Teknik Landfarming Terbuka. Institut Pertanian Bogor. Bogor

7. Anonim, 2010. Faktor-faktor yang mempengaruhi pertumbuhan bakteri, http://syariffauzi.wordpress.com/tag/ faktor-faktor-yang-mempengaruhipertumbuhan-bakteri/. online: accessed 25 Mei 2010,

8. Leahy JH., R. Colwell, 1990, Microbial degradation of Hydrocarbon in The
Environment. Microbiological Reviews 54:305-315

9. Black, J.G., 2002, Microbiology: principles and explorations, 5thed., John Wiley \& Sons, xxiv +762 hlm.

10. Das, N. \& P. Chandran, 2011, Microbial degradation of petroleum hydrocarbon contaminats:an overview. Biotech. Res. Int. Vol. 2011. pp: 1-13

11. Madjid, A. Dasar Dasar IImu Tanah. 2010. Univ. Sriwijaya. Palembang 